\title{
Analisis Perbandingan Isi Tajuk Rencana Surat Kabar Harian Analisa dan Waspada
}

\section{Comparative Analysis of Editorial of Analisa and Waspada Daily Newspaper}

\author{
Ade Nurainun dan Syafruddin Ritonga* \\ Ilmu Komunikasi, Fakultas Ilmu Sosial dan Ilmu Politik, Universitas Medan Area, Indonesia
}

\begin{abstract}
Abstrak
Surat Kabar Harian Analisa dan Waspada memiliki daerah pemasaran dan peliputan berita yang sama yakni dikota medan sendiri tentunya. Sehingga kedua surat kabar tersebut akan selalu terus bersaing dalam memperoleh berita. Hal ini juga memungkinkan keduanya akan memuat berita yang sama juga. Bisa jadi keduanya mengangkat peristiwa yang sama namun ditulis dengan sudut pandang yang berbeda. Perbedaan kedua surat kabar tersebut dilihat isi dari tajuk rencana, karena isi dari tajuk rencana merupakan opini yang ditulis oleh pimpinan pihak redaksinya sendiri. Sehingga wajar saja jika isi tajuk rencana berbeda antara surat kabar yang satu dengan surat kabar yang lainnya meskipun mengangkat permasalahan yang sama. Melalui tajuk rencana, redaksi dapat memberikan kritik dan saran baik itu terhadap pemerintah maupun pihak yang memiliki kepentingan kepada masyarakat. Hal ini dikarenakan tajuk rencana yang berisi informasi terhadap isu-isu yang sedang terjadi di masyarakat. Penelitian terhadap perbedaan isi tajuk rencana tersebut karena dilihat ada perbedaan kecenderungan surat kabar. Oleh sebab itu untuk melihat hal tersebut peneliti memilih menggunakan metode analisis isi. Dengan menggunakan metode tersebut peneliti bisa membuktikan bahwa Harian Analisa dan Waspada memang mempunyai perbedaan dalam tulisan yang diterbitkan dan yang dilihat dari isi tajuk rencana.

Kata Kunci: Analisis; Perbandingan Isi; Tajuk Rencana; Surat Kabar Harian
\end{abstract}

\begin{abstract}
Analisa and Waspada Daily Newspaper have the same marketing and news coverage area in their own city of course. So the two newspapers will always continue to compete in obtaining news. It also allows both of them to share the same news. It may be that both of them raise the same event but are written in different angles. The difference between the two newspapers is the content of the editorial, as the content of the editorial is an opinion written by the editor of the editor himself. So it is only natural that the content of the editorial differs from newspaper, even though it raises the same problem. Through editorials, the editor can provide both criticism and suggestions to the government as well as those with an interest to the community. This is because an editorial contains information on issues that are going on in the community. Research on the differences in the content of the editorial because there are differences in newspaper tendencies. Therefore, to see this the researcher chose to use content analysis method. Using this method, the researcher can prove that Analisa and Waspada Daily Alert do have differences in published writing and viewed from the content of the editorial.
\end{abstract}

Keywords: Analysis; Comparison of Content; Editorial; Daily Newspaper

How to Cite: Nurainun, A dan Syafruddin R., (2017). Analisis Perbandingan Isi Tajuk Rencana Surat Kabar Harian Analisa dan Waspada. JPPUMA: Jurnal Ilmu Pemerintahan dan Sosial Politik UMA, 5 (1): 31-41.

\footnotetext{
*Corresponding author:

E-mail: syafruddin@staff.uma.ac.id
}

p-ISSN: 25491660

e-ISSN: 2550-1305 


\section{PENDAHULUAN}

Perkembangan teknologi untuk mengakses pesan dalam bentuk informasi dan kebutuhan manusia akan informasi juga mempercepat timbulnya media massa seperti surat kabar, majalah, tabloid, radio dan televisi. Media yang sangat mudah dilihat dalam perkembangan media cetak adalah terutama surat kabar. Surat kabar merupakan media komunikasi massa dengan ruang lingkup yang begitu luas, karena khalayak pembacanya meliputi berbagai golongan dan khalayak masyarakat yang jumlahnya cukup besar.

Surat kabar menjadi alat komunikasi untuk menyampaikan pesan kepada pembaca dan sesuai dengan sifatnya yang tercetak dan kertas yang dicetak dalam bentuk sebuah koran yang berisi berbagai macam penyajian informasi berita yang terbit secara kontinyu atau biasanya harian. Maka dari itu surat kabar tidak akan terlepas dari konteks berita dan isinya.

Perusahaan-perusahaan surat kabar mulai melirik peristiwa-peristiwa daerah sebagai sumber berita, hal itu yang jadi melatar belakangi lahirnya surat kabar daerah atau biasa disebut surat kabar lokal. Saat ini setiap ibu kota provinsi dan beberapa kota besar termasuk kota medan sendiri sudah memiliki kantor surat kabar, bahkan ada yang memiliki kantor surat kabar lebih dari satu.

Di Kota Medan sendiri terdapat ada dua kantor pusat perusahaan surat kabar lokal yang telah lama berdiri atau bisa disebut juga paling tua diantara perusahaan surat kabar lain di kota medan ini yaitu surat kabar harian Waspada dan harian Analisa. Surat kabar lokal yang pertama kali terbit di Kota Medan adalah Waspada yang terbit sejak 11 Januari 1947 dan surat kabar ini terbitnya harian. Surat kabar harian Waspada ini didirikan oleh Mohammad Said dan Ani Idrus. Pusat kantor perusahaan surat kabar Harian Waspada terletak dijalan Letjen Suprapto atau Brigjen Katamso No. 1 Medan.

Harian Waspada Medan adalah salah satu surat kabar harian lokal kota Medan yang selalu menyediakan informasi dan juga peristiwa-peristiwa yang sedang terjadi di kota Medan dan sekitarnya. Saat ini sudah menjadi bacaan semua kalangan yaitu mulai dari pojok jalan, dikedai kopi maupun sampai disetiap rumah makan dikota atau diluar medan bahkan dimeja para pejabat dan birokrat negeri ini. Dengan membuat sajian isi berita yang menarik, independen dan berimbang dengan surat kabar lokal lainnya dalam mengulas sebuah berita, serta selalu menyajikan berita terhangat dan terbaru saat ini membuat para pelanggannya selalu setia membacanya.

Sedangkan surat kabar Harian Analisa adalah surat kabar harian yang terbit di kota Medan dan diterbitkan sejak 23 Maret 1972. Saat ini Harian Analisa dipimpin oleh Pemimpin Umum Supandi Kusuma. Harian Analisa merupakan salah satu surat kabar terbesar di kota Medan. Pada awalnya Analisa diterbitkan seminggu sekali sebelum menjadi surat kabar harian. Salah satu fitur Analisa yang paling terkenal dan ciri khas di surat kabar Analisa adalah gambar kartun Pak Tuntung yang muncul disetiap harinya kecuali minggu sejak 23 Maret 1973. Pusat kantor perusahaan surat kabar Harian Analisa adalah terletak di jalan Ahmad Yani No. 35-49 Medan. Harian Analisa melebarkan sayap hingga ke ibu kota, berarti sudah bisa dipastikan bahwa yang diedarkan Harian Analisa mampu mengimbangi surat kabar lokal kota besar lainnya maupun surat kabar nasional.

Segmentasi pembaca surat kabar harian Analisa dan Waspada tidak jauh berbeda dari wilayah pembaca dari kedua surat kabar tersebut yang didominasi oleh wilayah kota Medan dan sekitarnya. Meskipun demikian, Harian Analisa dan Waspada masing-masing memiliki daerah pemasaran yang lebih luas sampai kotakota besar lainnya. Untuk tingkat pembaca Harian Analisa dan Waspada didominasi oleh semua kalangan hingga khalayak umum yang lebih luas yang ada dikota Medan dan sekitarnya. 
Surat kabar akan selalu berusaha untuk menghasilkan isi berita yang berkualitas agar menarik perhatian para pembacanya. Kedua surat kabar yang akan diteliti memiliki daerah pemasaran dan peliputan berita yang sama yakni dikota medan sendiri tentunya. Sehingga kedua surat kabar tersebut akan selalu terus bersaing dalam memperoleh berita. Hal ini juga memungkinkan keduanya akan memuat berita yang sama juga. Bisa jadi keduanya mengangkat peristiwa yang sama namun ditulis dengan sudut pandang yang berbeda.

Perbedaan kedua surat kabar tersebut tidak bisa hanya dilihat dari berita tetapi juga dari isi opini atau artikel maupun tajuk rencana. Perbedaan isi yang paling mudah dilihat adalah melalui isi dari tajuk rencana, karena isi dari tajuk rencana merupakan opini yang ditulis oleh pimpinan pihak redaksinya sendiri. Sehingga wajar saja jika isi tajuk rencana berbeda antara surat kabar yang satu dengan surat kabar yang lainnya meskipun mengangkat permasalahan yang sama. Melalui tajuk rencana, redaksi dapat memberikan kritik dan saran baik itu terhadap pemerintah maupun pihak yang memiliki kepentingan kepada masyarakat. Hal ini dikarenakan tajuk rencana yang berisi informasi terhadap isu-isu yang sedang terjadi di masyarakat.

Melihat perbedaan dan persamaan diatas maka penulis ingin mengetahui apakah ada perbedaan yang signifikan dalam isi tajuk rencana pada surat kabar harian Analisa dan surat kabar harian Waspada jika ingin dilihat dari tema, haluan, jenis tajuk rencana, haluan kalimat, jenis kalimat, dan serta pemuatan moral dalam kalimat tajuk rencana.

Maka dari itu Penulis tertarik untuk melakukan penelitian terhadap perbedaan isi tajuk rencana tersebut karena menurut peneliti untuk melihat perbedaan kecenderungan surat kabar tersebut paling mudah dilihat dari penulisan tajuk rencananya. Oleh sebab itu untuk melihat hal tersebut peneliti memilih menggunakan metode analisis isi. Dengan menggunakan metode tersebut peneliti bisa membuktikan bahwa Harian Analisa dan Waspada memang mempunyai perbedaan dalam tulisan yang diterbitkan dan yang dilihat dari isi tajuk rencana.

\section{METODE PENELITIAN}

Metode yang digunakan dalam penelitian ini adalah analisis isi dan deskripsi yaitu penelitian yang bertujuan untuk melukiskan isi komunikasi yang nyata dan fenomena sosial. Penelitian ini bermaksud untuk mendeskripsikan isi tajuk rencana Surat Kabar Harian Analisa dan Waspada Edisi 1-31 Agustus 2016. Penelitian yang dilakukan tidak menggunakan lokasi dan waktu penelitian, karena penelitian ini menggunakan metode analisis isi. Penelitian ini juga tidak digunakannya manusia sebagai subjek penelitian untuk megisi angket ataupun kuesioner.

Populasi dan sampel memberikan batasan jumlah sampel yang akan digunakan selama penelitian. Dalam penelitian ini yang menjadi populasi adalah isi tajuk rencana yang dimuat dalam surat kabar Harian Analisa dan Waspada Medan Edisi 1-31 Agustus 2016 berjumlah 26 tajuk rencana, Sampel adalah seluruh tajuk rencana yang diteliti sebanyak 26 tajuk rencana.

Teknik pengumpulan data yang digunakan adalah teknik dokumentasi dan studi pustaka. Menurut Sukandarrumidi (2004:100) teknik dokumentasi merupakan teknik yang digunakan dalam upaya mencari dan menghimpun dokumen yang berupa tajuk rencana. Teknik

pengumpulan data dalam penelitian ini adalah sebagai berikut: Dokumentasi, peneliti menggunakan cara dengan mencari dan dokumen yang digunakan dalam mengumpulkan data yang berupa foto, surat kabar serta data-data hasil, catatan-catatan buku seperti teori, pendapat dari para ahli. Studi Pustaka, dengan membaca dan mengenal pengalaman-pengalaman orang lain, 
berarti mencari teori-teori, konsepkonsep, generalisasi-generalisasi, yang dapat dijadikan landasan teoritis bagi penelitian yang akan dilakukan itu (Margono, 1996: 76). Studi pustaka digunakan sebagai landasan teori yang tepat dalam penelitian yang akan dilakukan dan sebagai arah dalam melaksanakan penelitian.

Adapun teknik pengumpulan data yang digunakan dalam penelitian ini yaitu pengumpulan data akan dilakukan dengan cara mangamati, mencari perbandingan atau perbedaannya dan menghitung frekuensi dari isi tajuk rencana yang dimuat pada surat kabar harian Analisa dan Waspada edisi 1-31 agustus 2016.

Variabel penelitian ini terdiri dari dua variable yaitu variable independen (bebas) yaitu surat kabar (Analisa dan Waspada) dan variabel independen (terikat) yaitu tajuk rencana berisi tema, jenis tajuk rencana, haluan tajuk rencana, jenis kalimat, haluan kalimat, dan nilai moral.

Untuk memudahkan dan meletakkan konsep-konsep dalam jajaran operasional yang dapat diukur maka dibuat defenisi operasional. Defenisi operasional adalah sebuah unsur-unsur penelitian yang memberitahukan tentang cara mengukur variabel. Dengan kata lain defenisi operasional adalah semacam petunjuk pelaksanaan bagaimana mengukur suatu variabel-variabel tersebut.

Dapat dikatakan juga dengan bahasa yang lain bahwa defenisi operasional merupakan unsur penelitian yang memberitahukan cara bagaimana mengukur variabel. Perincian dari unit pengukuran dalam penelitian ini adalah frekuensi. Yang disebut frekuensi adalah tingkat dari keseringan tema, jenis, serta haluan dalam tajuk rencana yang mncul di surat kabar edisi tertentu. Dalam penelitian yang dimaksud dari tajuk rencana tersebut adalah tajuk rencana dari Surat Kabar Harian Analisa dan Waspada.

Untuk menganalisis data akan dilakukan dengan teknik metode analisis isi dengan pendekatan kuantitatif terhadap perbandingan isi tajuk rencana disurat kabar harian Analisa dan Waspada edisi 1-31 agustus 2016. Analisis data bertujuan untuk menyederhanakan data dalam bentuk yang lebih mudah dibaca dan diinterpretasikan. Analisis data dilakukan setelah data-data dikumpulkan dan disusun secara sistematik.

Adapun rumus chi-square sebagai berikut:

$$
X^{2}=\sum_{\frac{\left(f_{0}-f_{h}\right)^{2}}{f_{n}}}
$$

Keterangan :

Fo : Frekuensi yang didapat berdasarkan data yang diperoleh

Fh : Frekuensi yang diharapkan.

$\mathrm{X}^{2}$ : Keputusan:

1. : Apabila nilai $\mathrm{X}^{2}$ lebih kecil dari $\mathrm{X}^{2}$ krisis, maka ho diterima, artinya tidak ada perbedaan tajuk rencana Analisa dengan Waspada.

2. : Apabila nilai $\mathrm{X}^{2}$ lebih besar dari $\mathrm{X}^{2}$ krisis, maka $h_{1}$ diterima, artinya ada perbedaan tajuk rencana Analisa dengan Waspada.

\section{HASIL DAN PEMBAHASAN}

Tajuk rencana merupakan pendapat yang ditulis oleh redaktur surat kabar. Tajuk rencana digunakan oleh surat kabar untuk menyampaikan pandangan surat kabar terhadap permasalahan yang disoroti. Selain tajuk rencana redaksi juga memuat pendapat mereka dalam bentuk pojok dan karikatur. Perbedaan tajuk rencana dengan pojok atau karikatur terletak pada tingkat keseriusannya. Dimana tajuk rencana bersifat seirus sedangkan pojok dan karikatur lebih bernilai santai dan biasanya berupa sentilan.

Permasalahan yang diangkat dalam tajuk rencana merupakan permasalahan yang penting dan biasanya menjadi prioritas redaksi. Ulasan yang disampaikan dalam tajuk rencana diharapkan dapat memberikam pemahaman yang lebih mendalam kepada pembaca, sehingga pembawa bisa lebih peka terhadap 
permasalahan yang sedang terjadi. Karena tajuk rencana merupakan salah satu artikel yang bersifat subjektif, maka diharapkan tajuk rencana bisa memberi saran dan losusi terhadap permasalahan yang diangkat. Tajuk rencana biasanya ditempatkan bersamaan dengan artikel subjektif lainnya seperti esai, pojok, karikatur, komentar dan surat pembaca.

Analisis ini dilakukan untuk mengetahui seberapa jauh tingkat berikut.

Tabel 14. Nilai X² Tema Tajuk Rencana Harian Analisa dan Waspada

\begin{tabular}{|c|c|c|c|c|c|c|}
\hline No. & Variabel & Fo & fh & fo-fh & $(\text { fo-fh })^{2}$ & $\frac{(\mathrm{fo}-\mathrm{fh})^{2}}{f h}$ \\
\hline \multicolumn{7}{|c|}{ Analisa } \\
\hline 1 & Perang, pertahanan, dan diplomasi & 5 & 3,00 & 2,00 & 4,00 & 1,30 \\
\hline 2 & Politik dan pemerintahan & 3 & 8,50 & $-5,50$ & 30,30 & 3,60 \\
\hline 3 & Ekonomi & 7 & 4,00 & 3,00 & 9,00 & 2,30 \\
\hline 4 & Kejahatan & 2 & 3,50 & $-1,50$ & 2,30 & 0,60 \\
\hline 5 & $\begin{array}{l}\text { Kesehatan, dan kesejahteraan } \\
\text { masyarakat }\end{array}$ & 1 & 1,00 & 0,00 & 0,00 & 0,00 \\
\hline 6 & Human interest & 1 & 2,00 & $-1,00$ & 1,00 & 0,50 \\
\hline 7 & Ilmu pengetahuan & 0 & 0,00 & 0,00 & 0,00 & 0,00 \\
\hline 8 & Moral & 0 & 0,00 & 0,00 & 0,00 & 0,00 \\
\hline 9 & Kecelakaan dan bencana & 1 & 0,50 & 0,50 & 0,30 & 0,50 \\
\hline 10 & Pendidikan dan seni klasik & 6 & 3,50 & 2,50 & 6,30 & 1,80 \\
\hline 11 & Hiburan rakyat & 0 & 0,00 & 0,00 & 0,00 & 0,00 \\
\hline \multicolumn{7}{|c|}{ Waspada } \\
\hline 1 & Perang, pertahanan, dan diplomasi & 1 & 3,00 & 2,00 & 4,00 & 1,30 \\
\hline 2 & Politik dan pemerintahan & 14 & 8,50 & $-5,50$ & 30,30 & 3,60 \\
\hline 3 & Ekonomi & 1 & 4,00 & 3,00 & 9,00 & 2,30 \\
\hline 4 & Kejahatan & 5 & 3,50 & $-1,50$ & 2,30 & 0,60 \\
\hline 5 & $\begin{array}{l}\text { Kesehatan, dan kesejahteraan } \\
\text { masyarakat }\end{array}$ & 1 & 1,00 & 0,00 & 0,00 & 0,00 \\
\hline 6 & Human interest & 3 & 2,00 & $-1,00$ & 1,00 & 0,50 \\
\hline 7 & Ilmu pengetahuan & 0 & 0,00 & 0,00 & 0,00 & 0,00 \\
\hline 8 & Moral & 0 & 0,00 & 0,00 & 0,00 & 0,00 \\
\hline 9 & Kecelakaan dan bencana & 0 & 0,50 & 0,50 & 0,30 & 0,50 \\
\hline 10 & Pendidikan dan seni klasik & 1 & 3,50 & 2,50 & 6,30 & 1,80 \\
\hline 11 & Hiburan rakyat & 0 & 0,00 & 0,00 & 0,00 & 0,00 \\
\hline \multicolumn{2}{|c|}{ Jumlah } & 26 & 26 & 0 & 106,40 & 21,20 \\
\hline
\end{tabular}

Sumber : Perhitungan Peneliti

Berdasarkan hasil perhitungan di atas diperoleh angka $\mathrm{X}^{2}$ hitung sebesar 21,20 dan $\mathrm{X}^{2}$ tabel dengan derajat kebebasan $(\mathrm{dk})=$ $(\mathrm{n}-1)(\mathrm{k}-2)=(11-1)(2-1)=10$ pada taraf signifikansi 0,05 sebesar 18,31. Apabila $\mathrm{X}^{2}$ hitung lebih besar dari $\mathrm{X}^{2}$ tabel maka dapat dikatakan bahwa ada perbedaan yang signifikan dalam pemilihan tema tajuk

perbedaan antara tajuk rencana surat kabar Analisa dan Waspada pada periode bulan Agustus 2016. Perhitungan statistik menggunakan uji chi square terdiri dari kategori, tema, jenis, haluan, jenis kalimat, haluan kalimat dan nilai moral.

Berikut ini disajikan frekuensi yang diamati (fo) dengan frekuensi yang diharapkan (fh) untuk setiap subkategori dan nilai $\mathrm{X}^{2}$ tema tajuk rencana sebagai 
kabar Waspada lebih dominan memuat tentang politik dan pemerintahan mengenai tentang antisipasi kasus SARA di Tanjungbalai, usut penyebab rusuh Tanjungbalai, Edy Rahmayadi jadi Ketua Umum PSSI, jamaah risiko tinggi, deportasi pekerja cina, pembebasan sandera Abu Sayyaf, Jokowi versus Duterte, Nawacita, Menteri ESDM, perayaan HUT-71 Indonesia, mengkiritisi pidato Jokowi, masalah Danau Toba, perlindungan korban calo haji, audit perparkiran, teror IAH, dan masalah USU.
Sebagai surat kabar lokal, Analisa dan Waspada sering mengangkat tematema nasional dibandingkan dengan tema lokal. Meskipun demikian tidak tertutup kemungkinan kedua surat tersebut mengangkat tema internasional yang berkaitan dengan pemerintah Indonesia.

Analisis jenis tajuk rencana harian Analisa dan Waspada, Berikut ini disajikan frekuensi yang diamati (fo) dengan frekuensi yang diharapkan (fh) untuk setiap subkategori dan nilai $\mathrm{X}^{2}$ jenis tajuk rencana sebagai berikut.

Tabel 15. Nilai X² Jenis Tajuk Rencana Harian Analisa dan Waspada

\begin{tabular}{|l|l|l|l|l|l|l|}
\hline No. & Variabel & Fo & fh & fo-fh & $(\text { fo-fh })^{2}$ & $\frac{(\text { fo }- \text { fh })^{2}}{f h}$ \\
\hline Analisa \\
\hline $\mathbf{1}$ & Informatif & 11 & 14,00 & $-3,00$ & 9,00 & 0,60 \\
\hline $\mathbf{2}$ & Argumentatif & 15 & 11,50 & 3,50 & 12,30 & 1,10 \\
\hline 3 & Aneka Rupa & 0 & 0,50 & $-0,50$ & 0,30 & 0,50 \\
\hline \begin{tabular}{l}
$\mid$ Waspada a \\
\hline $\mathbf{1}$
\end{tabular} Informatif & 17 & 14,00 & 3,00 & 9,00 & 0,60 \\
\hline $\mathbf{2}$ & Argumentatif & 8 & 11,50 & $-3,50$ & 12,30 & 1,10 \\
\hline 3 & Aneka Rupa & 1 & 0,50 & 0,50 & 0,30 & 0,50 \\
\hline
\end{tabular}

Sumber : Perhitungan Peneliti

Berdasarkan hasil perhitungan di atas diperoleh angka $\mathrm{X}^{2}$ hitung sebesar 4,40 dan $\mathrm{X}^{2}$ tabel dengan derajat kebebasan $(\mathrm{dk})=$ $(\mathrm{n}-1)(\mathrm{k}-2)=(3-1)(2-1)=2$ pada taraf signifikansi o,05 sebesar 5,991. Apabila $X^{2}$ hitung lebih kecil dari $\mathrm{X}^{2}$ tabel maka dapat dikatakan bahwa tidak ada perbedaan yang signifikan jenis tajuk rencana antara surat kabar Analisa dengan Waspada.

Hal ini terbukti dari hasil pengamatan peneliti bahwa surat kabar Analisa cenderung lebih banyak memuat jenis tajuk rencana bersifat argumentatif dan surat kabar Waspada cenderung memuat jenis informatif. Namun proporsi keduanya tidak berbeda jauh sehingga tidak memiliki perbedaan yang bermakna. Selain itu kedua cenderung memuat jenis tajuk rencana yang berbeda, tetapi memiliki kecenderungan untuk lebih mendukung pemerintah dalam menyelesaikan masalah (favorable).

Analisis haluan tajuk rencana harian Analisa dan Waspada, berikut ini disajikan frekuensi yang diamati (fo) dengan frekuensi yang diharapkan (fh) untuk setiap subkategori dan nilai $\mathrm{X}^{2}$ haluan tajuk rencana sebagai berikut. 
JPPUMA: Jurnal Ilmu Pemerintahan dan Sosial Politik UMA, 5 (1) (2017): 31-41.

Tabel 16. Nilai X² Haluan Tajuk Rencana Harian Analisa dan Waspada

\begin{tabular}{|c|c|c|c|c|c|c|}
\hline No. & Variabel & Fo & fh & fo-fh & (fo-fh $)^{2}$ & $\frac{(\mathrm{fo}-\mathrm{fh})^{2}}{f h}$ \\
\hline \multicolumn{7}{|c|}{ Analisa } \\
\hline 1 & Favorable & 21 & 16,00 & 5,00 & 25,00 & 1,60 \\
\hline 2 & Unfavorable & 5 & 7,00 & $-2,00$ & 4,00 & 0,60 \\
\hline 3 & Netral & 0 & 3,00 & $-3,00$ & 9,00 & 3,00 \\
\hline \multicolumn{7}{|c|}{ Waspada } \\
\hline 1 & Favorable & 11 & 16,00 & $-5,00$ & 25,00 & 1,60 \\
\hline 2 & Unfavorable & 9 & 7,00 & 2,00 & 4,00 & 0,60 \\
\hline 3 & Netral & 6 & 3,00 & 3,00 & 9,00 & 3,00 \\
\hline \multicolumn{2}{|c|}{ Jumlah } & 52 & 52 & 0 & 76 & 10,40 \\
\hline
\end{tabular}

Sumber : Perhitungan Peneliti

Berdasarkan hasil perhitungan di atas diperoleh angka $\mathrm{X}^{2}$ hitung sebesar 10,40 dan $\mathrm{X}^{2}$ tabel dengan derajat kebebasan $(\mathrm{dk})=$ $(\mathrm{n}-1)(\mathrm{k}-2)=(3-1)(2-1)=2$ pada taraf signifikansi o,05 sebesar 5,991. Apabila $\mathrm{X}^{2}$ hitung lebih besar dari $\mathrm{X}^{2}$ tabel maka dapat dikatakan bahwa ada perbedaan yang signifikan haluan tajuk rencana antara surat kabar Analisa dengan Waspada.

Hal ini terbukti dari hasil pengamatan peneliti bahwa surat kabar Analisa dan Waspada cenderung lebih banyak memuat haluan tajuk rencana bersifat favorable, tentunya dengan proporsi yang sangat berbeda jauh. Haluan tajuk rencana yang dimuat kedua surat kabar tersebut cukup menarik. Artinya kedua surat kabar tersebut bukanlah yang hanya bisa menjadi oposisi bagi pemerintah, tetapi juga dapat mengambil posisi sebagai pendukung pemerintah selama program dan kegiatannya

bertujuann untuk meningkatkan kesejahteraan masyarakat.

Perbedaan yang terlihat jelas bahwa haluan tajuk rencana surat Analisa bersifat netral tidak ditemukan, tetapi surat kabar Waspada cukup banyak dimuat. Hal ini berarti surat kabar Analisa banyak mengangkat tema yang tidak berkaitan dengan pemerintah, maupun pihak yang kuat atau berkuasa. Dapat dikatakan bahwa surat Waspada merupakan media yang bersifat independen yang tidak memihak kepentingan manapun.

Analisis jenis kalimat dalam tajuk rencana harian Analisa dan Waspada, berikut ini disajikan frekuensi yang diamati (fo) dengan frekuensi yang diharapkan (fh) untuk setiap subkategori dan nilai $\mathrm{X}^{2}$ jenis kalimat dalam tajuk rencana sebagai berikut.

Tabel 17. Nilai X ${ }^{2}$ Jenis Kalimat dalam Tajuk Rencana Harian Analisa dan Waspada

\begin{tabular}{|l|l|l|l|l|l|l|}
\hline No. & Variabel & fo & fh & fo-fh & (fo-fh $)^{2}$ & $\frac{(\text { fo }- \text { fh })^{2}}{f h}$ \\
\hline Analisa & \multicolumn{5}{|l|}{} \\
\hline 1 & Informatif & 346 & 365,50 & $-19,50$ & 378,90 & 1,00 \\
\hline 2 & Argumentatif & 574 & 554,50 & 19,50 & 378,90 & 0,70 \\
\hline 3 & Aneka Rupa & 0 & 0,00 & 0,00 & 0,00 & 0,00 \\
\hline Waspada & Informatif & 375 & 355,50 & 19,50 & 378,90 & 1,10 \\
\hline 1 & Argumentatif & 520 & 539,50 & $-19,50$ & 378,90 & 0,70 \\
\hline 2 & 0 & 0,00 & 0,00 & 0,00 & 0,00 \\
\hline 3 & Aneka Rupa & 1815,00 & 1815,00 & 0 & 1515,60 & 3,50 \\
\hline
\end{tabular}

Sumber : Perhitungan Peneliti

Berdasarkan hasil perhitungan di $(\mathrm{n}-1)(\mathrm{k}-2)=(3-1)(2-1)=2$ pada taraf atas diperoleh angka $X^{2}$ hitung sebesar 3,50 signifikansi o,05 sebesar 5,991. Apabila dan $\mathrm{X}^{2}$ tabel dengan derajat kebebasan $(\mathrm{dk})=\mathrm{X}^{2}$ hitung lebih kecil dari $\mathrm{X}^{2}$ tabel maka dapat 
dikatakan bahwa tidak ada perbedaan yang signifikan haluan tajuk rencana antara surat kabar Analisa dengan Waspada.

Hal ini terbukti dari hasil pengamatan peneliti bahwa walaupun kedua surat kabar yaitu Analisa dan Waspada cenderung memuat jenis kalimat dalam tajuk rencana bersifat argumentatif dengan proporsi yang sangat besar perbedaannya tetapi kedua surat kabar tersebut tidak memuat jenis kalimat aneka rupa.

Kalimat-kalimat dalam tajuk rencana lebih banyak memuat kalimat argumentatif jika dibandingkan dengan kalimat informatif. Surat kabar Analisa memuat jenis kalimat argumentatif 574 kalimat, sedangkan jenis kalimat informatif sebanyak 346 kalimat. Demikian pula surat kabar Waspada memuat jenis kalimat argumentatif 520 kalimat, sedangkan jenis kalimat informatif sebanyak 375 kalimat.

Redaksi tajuk rencana dalam kedua surat kabar ingin menulis tajuk rencana yang

Tabel 18. Nilai X² Haluan Kalimat dalam Tajuk Rencana Harian Analisa dan Waspada

\begin{tabular}{|c|c|c|c|c|c|c|}
\hline No. & Variabel & Fo & fh & fo-fh & $(\text { fo-fh })^{2}$ & $\frac{(\mathrm{fo}-\mathrm{fh})^{2}}{f h}$ \\
\hline \multicolumn{7}{|c|}{ Analisa } \\
\hline 1 & Favorable & 711 & 545,40 & 165,60 & 27419,90 & 50,30 \\
\hline 2 & Unfavorable & 140 & 179,40 & $-39,40$ & 1555,40 & 8,70 \\
\hline 3 & Netral & 69 & 195,20 & $-126,20$ & 15914,20 & 0,00 \\
\hline \multicolumn{7}{|c|}{ Waspada } \\
\hline 1 & Favorable & 365 & 530,60 & $-165,60$ & 27419,90 & 51,70 \\
\hline 2 & Unfavorable & 214 & 174,60 & 39,40 & 1555,40 & 8,90 \\
\hline 3 & Netral & 316 & 189,80 & 126,20 & 15914,20 & 0,00 \\
\hline \multicolumn{2}{|c|}{ Jumlah } & $\begin{array}{l}1815,0 \\
0\end{array}$ & 1815,00 & 0 & 89779,00 & 119,5 \\
\hline
\end{tabular}

Sumber : Perhitungan Peneliti

Berdasarkan hasil perhitungan di atas diperoleh angka $\mathrm{X}^{2}$ hitung sebesar 119,60 dan $\mathrm{X}^{2}$ tabel dengan derajat kebebasan $(\mathrm{dk})=$ $(\mathrm{n}-1)(\mathrm{k}-2)=(3-1)(2-1)=2$ pada taraf signifikansi o,05 sebesar 5,991. Apabila $\mathrm{X}^{2}$ hitung lebih besar dari $\mathrm{X}^{2}$ tabel maka dapat dikatakan bahwa ada perbedaan yang signifikan haluan tajuk rencana antara surat kabar Analisa dengan Waspada.

Hal ini terbukti dari hasil pengamatan peneliti bahwa walaupun kedua surat kabar yaitu Analisa dan Waspada cenderung memuat haluan kalimat dalam tajuk rencana bersifat mampu menjadi guru. Tulisan tajuk rencana dapat dijadikan acuan atau pertimbangan pemerintah untuk mengambil kebijakan. Tajuk rencana jga memberikan analisis tentang permasalahan yang dihadapi oleh masyarakat, sehingga tajuk rencana dapat dijadikan dasar dalam melakukan prediksi atas suatu permasalahan karena didukung dengan data dan fakta.

Tajuk rencana yang dimuat dalam kedua surat kabar bersifat informatif dapat dijadikan sebagai dasar bagi redaksi untuk menentukan menjelaskan permasalahan atau suatu aktivitas yang diperoleh di lapangan didukung dengan data dan fakta.

Analisis haluan kalimat dalam tajuk rencana harian Analisa dan Waspada, berikut ini disajikan frekuensi yang diamati (fo) dengan frekuensi yang diharapkan (fh) untuk setiap subkategori dan nilai $\mathrm{X}^{2}$ haluan kalimat dalam tajuk rencana sebagai berikut. favorable, namun dengan proporsi yang sangat besar perbedaannya dan kedua surat kabar tersebut juga memuat haluam kalimat tidak memihak pemerintah atau pihak memiliki kuasa (netral) dengan proporsi sebesar $8 \%$ pada surat kabar Analisa dan sebesar 35\% pada surat kabar Waspada. Jika ditunjau dari proporsi tersebut memiliki persentase yang cukup berbeda. Banyak kalimat yang bersifat netral menunjukkan bahwa kedua surat kabar tersebut dapat muingkin untuk bersifat independen (tanpa memihak). 
Demkian juga haluan kalimat unfovorabel memiliki proporsi yang berbeda signifikan

Perbedaan kedua surat kabar tersebut juga dapat diamati dari haluan kalimat bersifat unfavorable cenderung memiliki proposi yang cukup besar perbedaannya. Walaupun kedua surat kabar ini dalam menyampaikan pendapatannya tidak mendukung pemerintah tetapi menguraikannya secara santun dan sopan. Kedua surat kabar tersebut juga berani menyampaikan kritikan memperhatikan etika dan nilai moral disertai dengan data dan fakta yang mendukung.

Analisis nilai mordal dalam kalimat tajuk rencana harian Analisa dan Waspada, berikut ini disajikan frekuensi yang diamati (fo) dengan frekuensi yang diharapkan (fh) untuk setiap subkategori dan nilai $\mathrm{X}^{2}$ nilai moral dalam tajuk rencana sebagai berikut.

Tabel 19. Nilai X² Nilai Moral dalam Kalimat Tajuk Rencana Harian Analisa dan Waspada

\begin{tabular}{|c|c|c|c|c|c|c|}
\hline No. & Variabel & Fo & $\mathrm{Fh}$ & fo-fh & $(\text { fo-fh })^{2}$ & $\frac{(\mathrm{fo}-\mathrm{fh})^{2}}{f h}$ \\
\hline \multicolumn{7}{|c|}{ Analisa } \\
\hline 1 & Positif & 710 & 647,80 & 62,20 & 3868,63 & 5,97 \\
\hline 2 & Negatif & 107 & 151,56 & $-44,56$ & 1985,52 & 13,10 \\
\hline 3 & Positif dan negatif & 84 & 78,57 & 5,43 & 29,51 & 0,00 \\
\hline 4 & Tidak mengandung nilai moral & 19 & 42,07 & $-23,07$ & 532,30 & 0,00 \\
\hline \multicolumn{7}{|c|}{ Waspada } \\
\hline 1 & Positif & 568 & 630,20 & $-62,20$ & 3868,63 & 6,14 \\
\hline 2 & Negatif & 192 & 147,44 & 44,56 & 1985,52 & 13,47 \\
\hline 3 & Positif dan negatif & 71 & 76,43 & $-5,43$ & 29,51 & 0,00 \\
\hline 4 & Tidak mengandung nilai moral & 64 & 40,93 & 23,07 & 532,30 & 0,00 \\
\hline \multicolumn{2}{|c|}{ Jumlah } & 1815,00 & 1815,00 & 0 & 12831,94 & 38,68 \\
\hline
\end{tabular}

Sumber : Perhitungan Peneliti

Berdasarkan hasil perhitungan di atas diperoleh angka $\mathrm{X}^{2}$ hitung sebesar 38,68 dan $\mathrm{X}^{2}$ tabel dengan derajat kebebasan $(\mathrm{dk})=$ $(\mathrm{n}-1)(\mathrm{k}-2)=(4-1)(2-1)=2$ pada taraf signifikansi o,05 sebesar 7,815. Apabila $\mathrm{X}^{2}$ hitung lebih besar dari $\mathrm{X}^{2}$ tabel maka dapat dikatakan bahwa ada perbedaan yang signifikan nilai moral dalam tajuk rencana antara surat kabar Analisa dengan Waspada.

Hal ini terbukti dari hasil pengamatan peneliti bahwa kedua surat kabar memiliki keragaman kalimat dalam memuat tajuk rencana. Kedua surat kabar tersebut mengandung nilai moral positif, negatif, atau nilai moral positif dan negaitf maupun kalimat yang tidak mengandung nilai moral. Meskipun memiliki perbedaan yang signifikan dalam kategori nilai moral yang dimuat, keduanya sama-sama lebih memberi tekanan kalimat yang dominan dalam pemuatan nilai moral positif daripada kalimat nilai moral negatif, maupun nilai moral positif dan negatif.

Sikap moral positif lebih mendapatkan sorotan oleh kedua surat kabar tersebut. Hal ini disebabkan kondisi moral bangsa Indonesia saat ini yang sangat memprihatikan terutama dalam upaya menegakkan reformasi dari segala aspek atau bidang untuk memajukan bangsa dan negara. Redaksi kedua surat kabar lebih menekankan nilai-nilai moral yang mendukung dalam mengembangkan perilaku ke arah yang baik untuk menutupi kerusakan moral agar pembaca dapat mengambil langkah-langkah menuju ke arah perbaikan. Artinya redaksi memuat nilai positif berfungsi sebagai pengawas atau kontrol dalam mengawasi jalannya pemerintah dengan mengubah kekurangan aparat-aparat pemerintah.

Sikap moral negatif yang dimuat menunjukkan kenegatifan atau dampak buruk, bagi masyarakat umum dan aparat 
pemerintah. Selain itu, banyaknya permasalahan-permasalahan sikap buruk yang dilakukan pemerintah menambah daftar permasalahan terutama hukum belum ditegakkan secara transparan dan adil.

\section{SIMPULAN}

Untuk mengetahui perbedaan kecenderungan penulisan tajuk rencana pada surat kabar Analisa dan Waspada, maka tajuk rencana yang dimuat oleh kedua surat kabar tersebut dimasukkan ke dalam kategori yang sudah ditetapkan. Setelah penyajian data dan menganalisisnya menggunakan rumus chi square, maka peneliti mengambil kesimpulan sebagai berikut. Hasil uji statistik menunjukkan ada perbedaan pemilihan tema tajuk rencana yang dimuat dalam Analisa dengan Waspada. Hal ini dikarenakan kedua surat kabar tersebut Analisa dan Waspada memiliki perbedaan tema tajuk rencana. Surat kabar Analisa cenderung lebih banyak memuat tema tentang ekonomi memiliki pengaruh yang besar terhadap kesejahteraan rakyat, sedangkan surat kabar Waspada lebih dominan memuat tentang politik dan pemerintahan. Hasil uji statistik menujukkan tidak ada perbedaan jenis tajuk rencana yang dimuat dalam Analisa dengan Waspada. Jenis tajuk rencana yang di muat di Analisa lebih sering adalah argumentatif yang dapat mempengaruhi para pembaca untuk mengikuti pendapat redaksi dalam menyelesaikan masalah. Tajuk rencana ini bertujuan mengungkapkan pendapat dan pandangan tentang permasalahan yang terjadi. Sedangkan harian Waspada cenderung didominasi jenis tajuk rencana informatif bertujuan untuk memberikan penjelasan dan gambaran tentang suatu masalah yang terjadi yang didukung dengan data dan fakta di lapangan. Hasil uji statistik chi square untuk haluan tajuk rencana bahwa ada perbedaan haluan tajuk rencana yang dimuat dalam Analisa dengan Waspada. Surat kabar harian Analisa dan Waspada lebih banyak memuat tajuk rencana favorable dengan proporsi yang jauh berbeda. Perbedaan ini juga terlihat jelas bahwa haluan tajuk rencana surat Analisa bersifat netral tidak ditemukan, tetapi surat kabar Waspada cukup banyak dimuat. Hasil uji statistik chi square untuk jenis kalimat dalam tajuk rencana bahwa tidak ada perbedaan jenis kalimat dalam tajuk rencana yang dimuat dalam Analisa dengan Waspada. Walaupun kedua surat kabar tersebut cenderung memuat jenis kalimat dalam tajuk rencana bersifat argumentatif dengan proporsi yang sangat besar perbedaannya tetapi kedua surat kabar ini juga tidak memuat jenis kalimat aneka rupa. Hasil uji statistik menunjukkan ada perbedaan haluan kalimat dalam tajuk rencana yang dimuat dalam Analisa dengan Waspada. Surat kabar Analisa dan Waspada lebih banyak memuat kalimat bersifat favorable, kemudian netral dan paling sedikit unfavorable. Kedua surat kabar tersebut bila ditinjau dari proporsi masing-masing kategori memiliki perbedaan jumlah yang signifikan. Hasil uji statistik menujukkan ada perbedaan nilai moral dalam tajuk rencana yang dimuat dalam Analisa dengan Waspada. Kedua surat kabar memiliki keragaman kalimat dalam memuat tajuk rencana yaitu mengandung nilai moral positif, negatif, atau nilai moral positif dan negaitf maupun kalimat yang tidak mengandung nilai moral.

\section{DAFTAR PUSTAKA}

Akhmadsyah, N. (1989). Gajahmada University Pers, Yogyakarta.

Abidin, Y. (2015). Metode Penelitian Komunikasi: Penelitian Kuantitatif; Teori dan Aplikasi. Bandung: Pustaka Setia.

Ardianto, E. (2004). Komunikasi Massa Suatu Pengantar. Bandung: Simbiosa Rekatama Media.

Ardianto E, Komala L \& Karlinah S. (2007). Komunikasi Massa Suatu Pengantar. Bandung: Refika offset.

Bertens, K. (1997). Etika. Gramedia Pustaka Utama. Jakarta.

Cangara, H. (2003). Dimensi Komunikasi. Jakarta: PT. Raja Grafindo Persada. 
(2003). Pengantar Ilmu Komunikasi. Jakarta: PT. Raja Grafindo Persada. (1986), .Dinamika Komunikasi. Bandung: Remaja Rosdakarya.

Effendi, O. (2003). Ilmu komunikasi: Teori dan Praktek. Bandung: Remaja Rosdakarya.

Eriyanto, (2011). Analisis Isi: Pengantar Metodologi Untuk Penelitian Komunikasi dan Ilmu Sosial Lainnya. Jakarta: Kecana Prenada Media Group.

Fiske, J. (2012). Pengantar Ilmu Komunikasi Edisi Ketiga. Jakarta: PT. Raja Grafindo Persada.

Flournoy, Don M. (ed). (1989). Analisis Isi Suratkabar-Suratkabar Indonesia. Terjemahan Akhmadsyah Naina. Yogyakarta: Gadjah Mada University Press.

Junaedhie, K. (2002). Ensiklopedi Pers Indonesia. Jakarta: Gramedia Pustaka Utama.

Kholil, S. (2006). Metodologi Penelitian Cetakan Pertama. Bandung: Cita Pustaka Media.

Margono, S. (1996). Metodologi Penelitian. Jakarta: Rineka Cipta.

Mc.Quail, D. (2005). Teori Komunikasi Massa: Suatu Pengantar. Jakarta: Penerbit Erlangga

Meinanda, T. (2003). Pengantar Ilmu Komunikasi. Bandung: Armico.

Muhtadi, A. (2004). Komunikasi Jurnalistik. Jakarta: Grassindo.

Mulyana, D. (2010). Ilmu Komunikasi: Suatu Pengantar. Bandung: Remaja Rosdakarya.

Nurudin, (2007). Pengantar Komunikasi Massa. Jakarta: PT. Raja Grafindo Persada.
Rakhmat, J. (2004). Metode Penelitian Komunikasi: Dilengkapi Contoh Analisis Statistik. Bandung: PT. Remaja Rosdakarya.

Romli, A. (2005). Jurnalistik Terapan. Bandung: Batik Press.

Sukandarrumidi. (2004). Metodologi Penelitian. Yogyakarta: Gadjah Mada University Press.

Sumadiria, Haris. (2005). Jurnalistik Indonesia: Menulis Berita dan Feature. Bandung: Simbiosa Rekatama Media. - (2011). Menulis Artikel dan Tajuk Rencana. Bandung: Simbiosa Rekatama Media.

Umar, Husein. (2002). Metode Riset Komunikasi Organisasi: Sebuah pendekatan Kuantitatif Dilengkapi dengan Contoh Proposal dan Hasil Riset Komunikasi Organisasi, Edisi ketiga. Jakarta: Gramedia Pustaka Utama.

Zuriah, N, (2007). Pendidikan Moral E Budi Pekerti Dalam Perspektif Perubahan, Jakarta: Bumi Aksara.

NN, 2016. "Tajuk Rencana”. Harian ANALISA, 1-31 Agustus 2016.

NN, 2016. "Tajuk Rencana”. Harian WASPADA, 1-31 Agustus 2016.

Istiqomah. 2011. Perbandingan Isi Tajuk Rencana Surat Kabar Solopos da Joglosemar Dalam Periode Juni sd Juni 2011,

(Online),(https://digilib.uns.ac.id/dokumen/d ownload/27607/NTgoMTQ=/Perbandin gan-Isi-Tajuk-Rencana-Surat-KabarAnalisis-Isi-Tentang-Perbandingan-IsiTajuk-Rencana-Antara-Surat-KabarSolopos-Dan-Joglosemar-DalamPeriode-Juni-Sampai-Dengan-Juli-2011abstrak.pdf, diakses 20 Oktober 2016). 